\title{
THE EFFECTIVENESS OF PROPRIOCEPTIVE NEUROMUSCULAR FACILITATION IN MECHANICAL NECK PAIN: A SYSTEMATIC REVIEW
}

Made Hendra Satria Nugraha ${ }^{1}$ Anak Agung Gede Angga Puspa Negara ${ }^{2}$ Ni Komang Ayu Juni Antari $^{3}$ Anak Ayu Nyoman Trisna Narta Dewi ${ }^{4}$

1,2,3,4 Physiotherapy Department, Faculty of Medicine, Udayana University

Correspondent email: hendra_satria@unud.ac.id

\begin{abstract}
Introduction: Neck pain is a health condition that has a high incidence rate and causes an inability to do daily activities and requires cost in handling it. People with neck pain could be associated with an alteration and deficit of the proprioception of the muscle and neck joint that play a significant role in joint position, postural stability, and motor control of the head and neck. The purpose of this systematic review is to find out the effectiveness of proprioceptive neuromuscular facilitation (PNF) and other recommendation related to application method and dosage of PNF in treating mechanical neck pain. Method: The systematic review access to journal databases such as: PubMed Central (PMC) NCBI, Physiotherapy Evidence Database (PEDro), ProQuest, Google Scholar, MEDLINE, and the Cochrane Controlled Trials Register in the Cochrane Library. Results: The initial search in 6 databases found a total of 30 articles. Based on inclusion and exclusion criteria 4 articles were used in this systematic review. The application of the muscle energy techniques was applied ranging from 1 time to 8 weeks of intervention. From the 4 reviewed studies concluded that proprioceptive neuromuscular facilitation was effective in improving neck range of motion and function in mechanical neck pain. Conclusion: Based on the results of this systematic review it can be concluded that proprioceptive neuromuscular facilitation is effective in improving pain, pain threshold, range of motion, and functional performance in individual with neck pain. The appropriate articles are still limited to 4 studies, but have good to strong qualities. In addition, the application of intervention does not have the same standard.
\end{abstract}

Key words: mechanical neck pain; proprioceptive neuromuscular facilitation; systematic review

\section{BACKGROUND}

Neck pain is a common problem in musculoskeletal condition with an increased disability in 29 million in 2016. Neck pain is ultimately being described as non-specific neck pain because it cannot be assigned a specific cause of the symptoms in majority of patients. ${ }^{(1)}$ It becomes a chronic pain, if the duration of symptoms is greater than 12 weeks. ${ }^{(2)}$ Neck pain is the third most frequently self-reported in musculoskeletal area in the Netherland. It becomes an important social and health problem affecting up two thirds individual in their lives and make the cost of neck pain become high in primary care. ${ }^{(3)}$

People with neck pain could be associated with an alteration and deficit of the proprioception of the muscle and neck joint that play a significant role in joint position, postural stability, and motor control of the head and neck. ${ }^{(2)}$ Evidence is currently inconclusive for the treatment efficacy of subacute and chronic neck pain. Many non-pharmacological therapy can be used to treat neck pain, such as electro physical agent, exercise therapy, and manual therapy. A study shown that there is a significant differences in effectiveness and cost-effectiveness in using manual therapy compared to exercise therapy or usual general practitioner care in patients with sub-acute and chronic neck pain. ${ }^{(3)}$

Proprioceptive Neuromuscular Facilitation (PNF) is an example of the application of exercise therapy. PNF applies neurophysiology principles such as sensory/motor system to evaluate or treat of neuromuscular problem. PNF provides an efficient technique to treat neuromuscular and structural dysfunction. ${ }^{(4)}$ Several studies have proven that the application of PNF can reduce pain, improve the range of motion, and reduce the degree of neck disability. ${ }^{(5)(6)(7)(8)}$ However, the recommendation of application method and dosage have not been widely discussed by some previous studies. Based on that background, the goals to be achieved from this systematic review is to find out the effectiveness of PNF 
and other recommendation related to the application method and PNF dosage in treating mechanical neck pain.

\section{METHOD}

a. Search strategy

This systematic review access to journal database such as: PubMed Central (PMC) NCBI, PEDro, ProQuest, Google Scholar, MEDLINE, and the Cochrane Controlled Trials Register in the Cochrane Library. Search strategy using keywords: 'proprioceptive neuromuscular facilitation' and 'neck pain'.

b. Inclusion/exclusion criteria

Inclusion criteria include: (1) Journal articles with randomized controlled trial (RCT) research designs, (2) Article must be in English, (3) Articles published in the last 15 years (September 2004 September 2019). While the exclusion criteria include: (1) If there is the same article, then other articles are excluded, (2) conference proceedings, abstracts, thesis, or case reports.

c. Study selection

The inclusion and exclusion criteria are independently applied by four reviewers. The full text of each study, then screened by these reviewers to determine if they met criteria. Discussion is used to resolve if there were disagreements in consensus.

d. Study quality assessment

To assess the quality of the studies, we used The Standard Quality Assessment Criteria for Evaluating Primary Research Paper from a Variety of Fields. This assessment criteria consist of a 14item assessment checklist in which points were awarded to each criterion $(\mathrm{no}=0$, partial $=1$, and yes $=2$ ). This assessment criteria is a validated standard. ${ }^{(9)}$ Article quality assessment was assessed by dividing the total assessment score by 28 then categorized into: limited $(<50 \%)$, adequate $(50 \%-69 \%)$, good $(70 \%-80 \%)$, or strong (score of $>80 \%)$. Studied were excluded from this review, if the percentage scores below $50 \%$. Discussion is used to resolve if there were disagreements in consensus. ${ }^{(10)}$

e. Data extraction

Data were extracted by summarizing data on description of participants, intervention group, control/comparison group, outcome measures, results, and quality rating of the study.

\section{RESULTS}

a. Study selection

The initial search in 6 databases found a total of 30 articles. Then the selection using inclusion and exclusion criteria obtained 7 articles. The same article was then excluded. The total articles used in this study amounted to 4 articles. Explanation regarding study selection, described in Figure 1.

b. Methodological quality and risk of bias of included studies

After assessing the quality of the study, there is no article was excluded because they had a score of $<50 \%$. The articles obtained have a strong category for 2 and good for 2 studies. Explanation regarding the quality assessment of journals, described in Table 1.

c. Study characteristics

The 5 included studies had a total of 150 participants. The age of participants ranged between 18-53 years old. The sample sizes of studies ranged from 11 to 22 subjects. The characteristics of the summary of the study results used in this review are summarized in Table 2. 

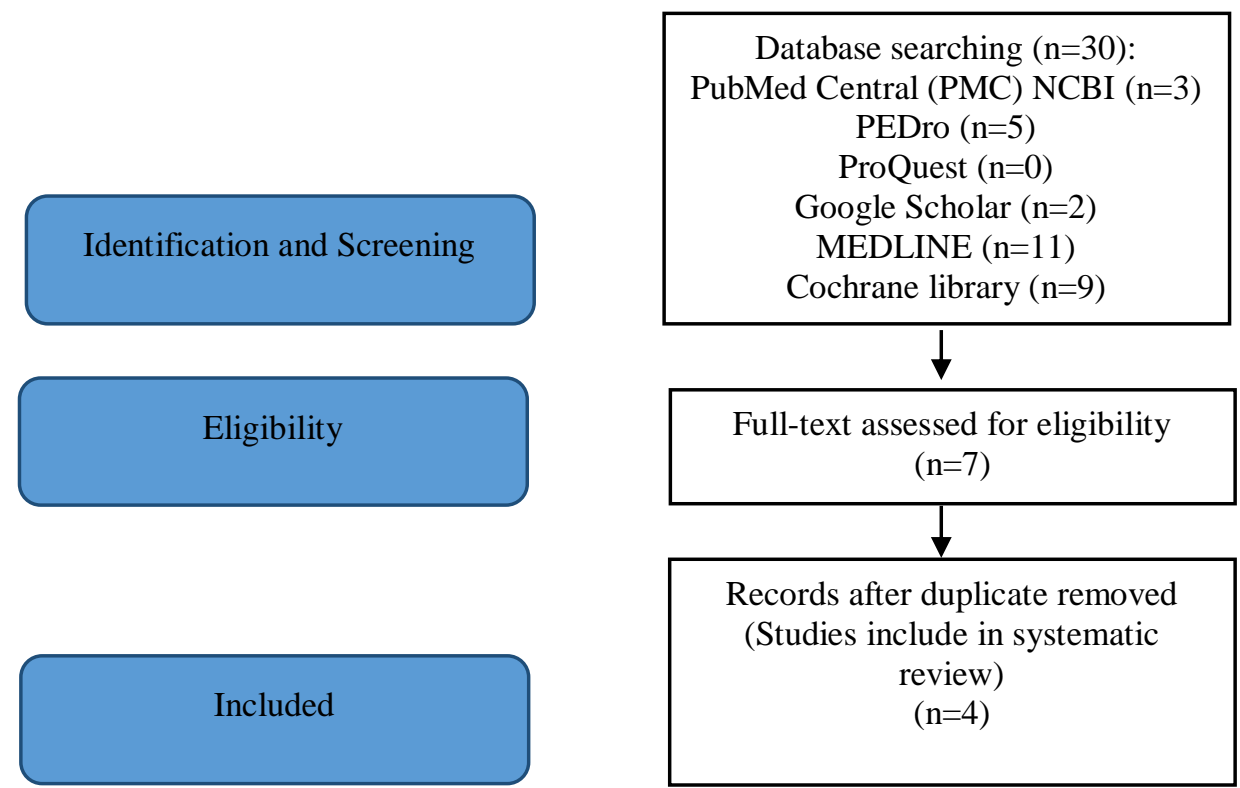

Figure 1. A flow chart of search strategy

Table 1. Methodological quality of included studies

\begin{tabular}{|c|c|c|c|c|c|c|c|c|c|c|c|c|c|c|}
\hline \multirow[t]{2}{*}{ Study } & \multicolumn{14}{|c|}{ Items on standard quality assessment checklist } \\
\hline & 1 & 2 & 3 & 4 & 5 & 6 & 7 & 8 & 9 & 10 & 11 & 12 & 13 & 14 \\
\hline Palmgren et al., $2006^{(5)}$ & + & + & + & + & \pm & + & \pm & + & \pm & + & \pm & \pm & + & + \\
\hline Jung-Ho et al., $2013^{(6)}$ & + & + & + & + & \pm & - & - & + & \pm & + & \pm & \pm & + & + \\
\hline Jung-Ho and Eun-Yeong, $2013^{(7)}$ & + & + & + & + & \pm & - & - & + & \pm & + & \pm & \pm & + & + \\
\hline Parisa, et al., $2016^{(8)}$ & + & + & + & + & \pm & \pm & \pm & + & + & + & \pm & + & + & + \\
\hline
\end{tabular}

$+=$ yes; - = no; $\pm=$ partial

Table 2. Characteristics of included studies describing the efficacy of muscle energy technique

\begin{tabular}{|c|c|c|c|c|c|c|}
\hline Author & Sample & Intervention & $\begin{array}{l}\text { Control/comp } \\
\text { arison }\end{array}$ & Outcome measures & Results & $\begin{array}{l}\text { Quality } \\
\text { rating }\end{array}$ \\
\hline $\begin{array}{l}\text { Palmgren et } \\
\text { al., } 2006^{(5)}\end{array}$ & $\begin{array}{l}\mathrm{N}=41 \\
\text { Age range: } 18 \\
-53\end{array}$ & $\begin{array}{l}\text { Advice and regular } \\
\text { exercise } \\
\text { chiropractic therapy } \\
\text { (high-velocity and } \\
\text { low-amplitude } \\
\text { techniques, ischemic } \\
\text { compression on } \\
\text { myofascial trigger } \\
\text { points, and spine- } \\
\text { stabilizing exercises } \\
\text { or proprioceptive } \\
\text { neuromuscular } \\
\text { facilitation (PNF) } \\
\text { targeted toward } \\
\text { hypomobile } \\
\text { zygapophyseal joints } \\
\text { in the cervical and } \\
\text { cervicothoracic } \\
\text { region (n=21) }\end{array}$ & $\begin{array}{l}\begin{array}{l}\text { Advice and } \\
\text { regular } \\
\text { exercise. } \\
(\mathrm{n}=20)\end{array} \\
\text { Dossage: } 3 \text { - } \\
5 \text { sessions } \\
\text { during a 5- } \\
\text { week period. }\end{array}$ & $\begin{array}{l}\text { Outcome measure } \\
\text { was assessed at } \\
\text { pre-treatment and } \\
\text { the end of 5-week } \\
\text { study. } \\
\text { - Neck pain: Visual } \\
\text { Analogue Scale } \\
\text { (VAS). } \\
\text { Cervical range of } \\
\text { motion (CROM): } \\
\text { goniometer. } \\
\text { The ability of the } \\
\text { neuroarticulomus } \\
\text { cular: head } \\
\text { repositioning } \\
\text { accuracy (HRA): }\end{array}$ & $\begin{array}{l}\text { The results } \\
\text { showed } \\
\text { significantly } \\
\text { greater } \\
\text { improvements in } \\
\text { pain and HRA } \\
\text { aspects were } \\
\text { detected in the } \\
\text { intervention } \\
\text { group. }\end{array}$ & $\begin{array}{l}\text { Strong } \\
23 / 28 \\
82,14 \%\end{array}$ \\
\hline & & $\begin{array}{l}\text { Dossage: } 3-5 \text { times } \\
\text { for } 5 \text { weeks. }\end{array}$ & & & & \\
\hline
\end{tabular}




\begin{tabular}{|c|c|c|c|c|c|c|c|}
\hline $\begin{array}{l}\text { Jung-Ho et } \\
\text { al., } 2013^{(6)}\end{array}$ & $\begin{array}{l}\mathrm{N}=32 \\
\text { Age range: } \pm \\
47 \text { years old. }\end{array}$ & $\begin{array}{l}\text { General PT technique } \\
\text { (hot pack for } 20 \\
\text { minutes, ultrasound } \\
\text { therapy for five } \\
\text { minutes, and } \\
\text { transcutaneous } \\
\text { electrical nerve } \\
\text { stimulation for } 20 \\
\text { minutes) and muscle } \\
\text { relaxation therapy } \\
\text { (hold-relax PNF } \\
\text { technique) and } \\
\text { shoulder joint } \\
\text { stabilizing exercises } \\
\text { ( } 3 \text { sets, } 5 \text { repetitions, } \\
3 \text { minutes rest) } \\
\text { (n=16) } \\
\text { Dosage: } 1 \text { session. }\end{array}$ & $\begin{array}{l}\text { General PT } \\
\text { technique } \\
(\mathrm{n}=16) \\
\text { Dosage: } 1 \\
\text { session. }\end{array}$ & - & $\begin{array}{l}\text { Outcome measure } \\
\text { was assessed at } \\
\text { pre-treatment and } \\
\text { after treatment. } \\
\text { Neck pain: VAS. } \\
\text { Pressure pain } \\
\text { threshold (PPT): } \\
\text { pressure } \\
\text { algometer } \\
\text { Functional } \\
\text { performance: } \\
\text { Neck disability } \\
\text { index (NDI). } \\
\text { Shoulder joint } \\
\text { functions: } \\
\text { constant-murley } \\
\text { scale (CMS). }\end{array}$ & $\begin{array}{l}\text { The results } \\
\text { showed } \\
\text { significantly } \\
\text { greater } \\
\text { improvements in } \\
\text { postures, internal } \\
\text { rotation, and } \\
\text { external rotation } \\
\text { among the CMS } \\
\text { items were } \\
\text { detected in the } \\
\text { intervention } \\
\text { group. }\end{array}$ & $\begin{array}{l}\text { Good } \\
20 / 28 \\
71,43 \%\end{array}$ \\
\hline $\begin{array}{l}\text { Jung-Ho } \\
\text { and Eun- } \\
\text { Yeong, } \\
2013^{(7)}\end{array}$ & $\begin{array}{l}\mathrm{N}=33 \\
\text { Age range: } \pm \\
51 \text { years old. }\end{array}$ & $\begin{array}{l}\text { Group 1: } \\
\text { Conventional therapy } \\
\text { (ultrasound therapy } \\
\text { for } 5 \text { minutes and hot } \\
\text { pack therapy for } 20 \\
\text { minutes) + PNF } \\
\text { (hold-relax } \\
\text { technique). } \\
\text { ( } \mathrm{n}=11 \text { ) } \\
\text { Group 2: } \\
\text { Conventional therapy } \\
+ \text { extracorporeal } \\
\text { shockwave therapy } \\
\text { (ESWT) (1000 times } \\
\text { to the trigger point of } \\
\text { the upper trapezius } \\
\text { muscle at } 5 \text { Hz) } \\
\text { (n=11) } \\
\text { Dosage: twice per } \\
\text { week for } 4 \text { weeks. }\end{array}$ & $\begin{array}{l}\text { Conventional } \\
\text { therapy }+ \\
\text { trigger point } \\
\text { injection } \\
\text { (TPI) }(0.2 \mathrm{~mL} \\
\text { of } 0.3 \% \\
\text { lidocaine) } \\
\text { ( } \mathrm{n}=11) \\
\text { Dosage: two } \\
\text { times per } \\
\text { week for } 4 \\
\text { weeks. }\end{array}$ & - & $\begin{array}{l}\text { Outcome measure } \\
\text { was assessed at } \\
\text { pre-treatment and } \\
\text { the end of 4-week } \\
\text { study. } \\
\text { Neck pain: VAS. } \\
\text { Pressure pain } \\
\text { threshold (PPT): } \\
\text { pressure } \\
\text { algometer } \\
\text { Functional } \\
\text { performance:NDI } \\
\text { Shoulder joint } \\
\text { functions: CMS. }\end{array}$ & $\begin{array}{l}\text { The results } \\
\text { showed PNF } \\
\text { treatment } \\
\text { enhanced range } \\
\text { of motion in the } \\
\text { shoulder joint, } \\
\text { neck function, } \\
\text { and activities of } \\
\text { daily living } \\
\text { relative to the } \\
\text { other methods; } \\
\text { ESWT improved } \\
\text { function and } \\
\text { reduced degree of } \\
\text { pain; TPI } \\
\text { treatment reduced } \\
\text { pain, but had } \\
\text { limited effects in } \\
\text { enhancing } \\
\text { functional } \\
\text { activities. }\end{array}$ & $\begin{array}{l}\text { Good } \\
20 / 28 \\
71,43 \%\end{array}$ \\
\hline $\begin{array}{l}\text { Parisa, et } \\
\text { al., } 2016^{(8)}\end{array}$ & $\begin{array}{l}\mathrm{N}=44 \\
\text { Age range: } 22 \\
-32 .\end{array}$ & $\begin{array}{l}\text { Stabilization exercise } \\
(\mathrm{SE}) \\
(\mathrm{n}=22)\end{array}$ & $\begin{array}{l}\begin{array}{l}\text { PNF } \\
(\mathrm{n}=22)\end{array} \\
\text { Dosage: } 6 \\
\text { times per } \\
\text { week and } 2 \\
\text { times per day } \\
\text { for } 8 \text { weeks. }\end{array}$ & - & $\begin{array}{l}\text { Outcome measure } \\
\text { was assessed at } \\
\text { pre-treatment and } \\
\text { the end of } 8 \text {-week } \\
\text { study. } \\
\text { Neck pain: VAS. } \\
\text { Functional } \\
\text { performance: } \\
\text { NDI. } \\
\text { Cross-sectional } \\
\text { area of deep neck } \\
\text { flexor muscles: } \\
\text { ultrasonic } \\
\text { ultrasonography } \\
\text { device. }\end{array}$ & $\begin{array}{l}\text { The results } \\
\text { showed that both } \\
\text { methods of SE } \\
\text { and } \\
\text { effective PNF } \\
\text { reduced pain and } \\
\text { disability. SE had } \\
\text { better effects in } \\
\text { increasing the } \\
\text { cross-sectional } \\
\text { area of deep } \\
\text { flexor muscles. }\end{array}$ & $\begin{array}{l}\text { Strong } \\
24 / 28 \\
85,71 \%\end{array}$ \\
\hline
\end{tabular}




\section{DISCUSSION}

The application of the PNF was applied ranging from 1 time to 8 weeks of intervention. From the 4 reviewed articles concluded that proprioceptive neuromuscular facilitation was effective in improving pain, range of motion, pain threshold, and functional performance in individual with neck pain. Table 3 describes the outcome measure used in this study to evaluate the limitations of body function and movement in neck pain based on The International Classification of Functioning, Disability and Health (ICF) criteria.

Table 3. Outcome measure used in the study

\begin{tabular}{lccccc}
\hline Study & \multicolumn{5}{c}{ Treatment Outcomes } \\
\cline { 2 - 5 } & Pain & Pain Threshold & $\begin{array}{c}\text { Range of } \\
\text { motion }\end{array}$ & $\begin{array}{c}\text { Functional } \\
\text { performance }\end{array}$ & $\begin{array}{c}\text { The ability of the } \\
\text { neuro } \\
\text { articulomuscular }\end{array}$ \\
\hline Palmgrectional area
\end{tabular}

Previous research assessed the efficacy of combination of PNF and conventional physiotherapy versus conventional physiotherapy on pain and function in a study of 32 subjects with neck pain. The results showed that the combination of PNF and conventional physiotherapy is significantly better than conventional physiotherapy in improving postures, internal and external rotation movement in individual with neck pain. It can be concluded that PNF technique effective in improving the function of neck pain patients. ${ }^{(6)}$

Another research performed a study on 33 patients with myofascial pain syndrome. They divided patients into 3 groups. All groups received general physiotherapy. First group received PNF using the hold-relax technique. Second group received the shock wave therapy. Third group received injection therapy. The result showed that PNF methods enhanced neck function, range of motion in shoulder joint, and activities daily living compared to the other methods. ${ }^{(7)}$

Another study perform on 44 subjects with chronic non-specific neck pain. The subjects were randomly divided into two groups, into stabilizing exercise and proprioceptive neuromuscular facilitation. The result showed that both methods are in improving neck pain and disability, meanwhile the stabilizing exercise had a better impact in increasing cross-sectional area of the muscle. ${ }^{(8)}$

PNF is a dynamic approach to treat a neuromuscular problem. PNF applies neurophysiology principles such as sensory/motor system to evaluate or treat of neuromuscular problem. PNF provides an efficient technique to treat neuromuscular and structural dysfunction. Structural dysfunctions is defined as a condition that affect the body posture such as the myofascial and articular mobility. Neuromuscular dysfunctions related to the inability efficiently perform a purposeful movement caused by neural irritation or damage. The goal of PNF approach are to facilitate structural and neuromuscular system and reduce the symptoms, improves the distributions of force, and reduce the functional stresses caused by poor neuromuscular control. The basic principle of facilitation that used by the PNF, namely: manual contact, resistance, irradiation and reinforcement, body position and body mechanic, visual stimulation, auditory stimulation (command), traction or approximation, stretch, timing, and patterns. ${ }^{(4)}$

Previous researcher describe the technique which is used on their study as a hold relax technique. ${ }^{(6)(7)}$ Hold relax is used to facilitate relaxation and increasing the range of motion. It used an isometric contraction rather than an isotonic contraction. It creates indirect relaxation through irradiation. Hold relax can be divided into two methods, namely: direct and indirect technique. When therapist apply the direct technique, it allows the isometric contraction of the antagonistic muscle to shorten followed by relaxation. In the indirect technique therapist resist the synergists muscle. This technique indicated when the contraction of the restricted muscle is too painful. Other review recommend about the PNF technique which is used to treat the patients. PNF is sufficient to increase the range of motion when apply twice a week, even with single repetition. Static contraction should be held for 3 seconds and using $20 \%$ of a maximal static contraction of the target muscle. ${ }^{(11)}$ 


\section{CONCLUSION}

Based on the results of this systematic review it can be concluded that proprioceptive neuromuscular facilitation is effective in improving pain, pain threshold, range of motion, and functional performance in individual with neck pain. The appropriate articles are still limited to 4 studies, but have good to strong qualities. In addition, the application of intervention does not have the same standard.

\section{REFERENCES}

1. Domingues L, Pimentel-Santos FM, Cruz EB, Sousa AC, Santos A, Cordovil A, et al. Is a combined programme of manual therapy and exercise more effective than usual care in patients with non-specific chronic neck pain? A randomized controlled trial. Clin Rehabil. 2019;33(12):1908-18.

2. Bernal-Utrera C, González-Gerez JJ, Saavedra-Hernandez M, Lérida-Ortega MÁ, Rodríguez-Blanco C. Manual therapy versus therapeutic exercise in non-specific chronic neck pain: Study protocol for a randomized controlled trial. Trials. 2019;20(1):1-6.

3. Groeneweg R, van Assen L, Kropman H, Leopold H, Mulder J, Smits-Engelsman BCM, et al. Manual therapy compared with physical therapy in patients with non-specific neck pain: A randomized controlled trial. Chiropr Man Ther. 2017;25(1):1-12.

4. Adler SS, Beckers D, Buck M. PNF in Practice. Fourth. Botsch M, editor. Physiotherapy. Heidelberg: Springer Medizin; 2013. 249-250 p.

5. Palmgren PJ, Sandström PJ, Lundqvist FJ, Heikkilä H. Improvement after chiropractic care in cervicocephalic kinesthetic sensibility and subjective pain intensity in patients with nontraumatic chronic neck pain. J Manipulative Physiol Ther. 2006;29(2):100-6.

6. Lee JH, Park SJ, Na SS. The effect of proprioceptive neuromuscular facilitation therapy on pain and function. J Phys Ther Sci. 2013;25(6):713-6.

7. Lee JH, Han EY. A comparison of the effects of PNF, ESWT, and TPI on pain and function of patients with myofascial pain syndrome. J Phys Ther Sci. 2013;25(3):341-4.

8. Parisa GH, Ahmadreza AA, Mohammad H, Asghar A, Leila R, Fateme G. Investigating the effect of stabilization exercise and proprioceptive neuromuscular facilitation exercises on cross-sectional area of deep cervical flexor muscles in patients with chronic non-specific neck pain. Int J Med Res Heal Sci. 2016;5(11):502-8.

9. Kmet LM, Lee RC, Cook LS. Standard quality assessment criteria for evaluating primary research papers from a variety of fields. [Internet]. HTA Initiative. 2004. 1-22 p. Available from: https://www.ihe.ca/advanced-search/standard-quality-assessment-criteria-for-evaluating-primaryresearch-papers-from-a-variety-of-fields

10. Lim YH, Chee DY, Girdler S, Lee HC. Median nerve mobilization techniques in the treatment of carpal tunnel syndrome: A systematic review. J Hand Ther [Internet]. 2017;30(4):397-406. Available from: http://dx.doi.org/10.1016/j.jht.2017.06.019

11. Sharman MJ, Cresswell AG, Riek S. Proprioceptive neuromuscular facilitation stretching: Mechanisms and clinical implications. Sport Med. 2006;36(11):929-39. 